\title{
COMPARISON OF GEO-MECHANICAL PROPERTIES OF WHITE ROCK SALT AND PINK ROCK SALT IN KŁODAWA SALT DIAPIR
}

\author{
Malwina Kolano, Danuta FlisiaK \\ Faculty of Mining and Geoengineering, AGH University of Science and Technology, \\ 30 Mickiewicza Av., 30-059 Kraków, Poland. \\ E-mail: mkolano@agh.edu.pl,danutafl1@ineria.pl
}

\begin{abstract}
Within the boundaries of the Salt Mine "Kłodawa", rock-salts and potassium-magnesium salts occur at different stratigraphic levels. The present article introduces strength-strain properties of white rock salt, building the nucleus of northeastern edge anticline, and pink rock salt that belongs to the series of youngest rock salt.

On the grounds of the research on strength and strain parameters (uniaxial compressive and tensile strength, triaxial shear strength, modulus of elasticity and Poisson ratio) there is presented, in the article, variation of basic parameters determining geo-mechanical properties of rock salt in Kłodawa salt diapir.
\end{abstract}

\section{INTRODUCTION}

Kłodawa diapir is located within the salt structure of Izbica Kujawsko-Łęczycka. This structure is situated on western edge of kujawski embankment. It is underground object, covered with Tertiary and Quaternary sediments, which is longitudinal anticlinal form. In the nucleus of this anticline, there are saliferous Permian limestone deposits, which get upwards through strongly-vaulted Mesozoic formation. Kłodawa diapir spreads from northwest to southeast at the length of $26 \mathrm{~km}$. Its width in the upper part ranges from 0.5 to $2 \mathrm{~km} \mathrm{[3].}$

Useful minerals in Kłodawa diapir are rock salts and potassium-magnesium salts [2]. Within the mine boundaries rock salts and potassium-magnesium salts occur at the following stratigraphic levels:

- older white rock salt,

- older potassium salt,

- kieserite carnallite,

- non-kieserite carnallite,

- youngest pink rock salt.

Geo-mechanical properties of white rock salt were put to laboratory tests, the one taken in field 2, and the youngest pink rock salt taken in fields 3 and 5 (Fig. 1). In the present paper, there are presented the results of uniaxial and triaxial compressive and tensile tests done by means of transverse compression method (Brazilian method). 


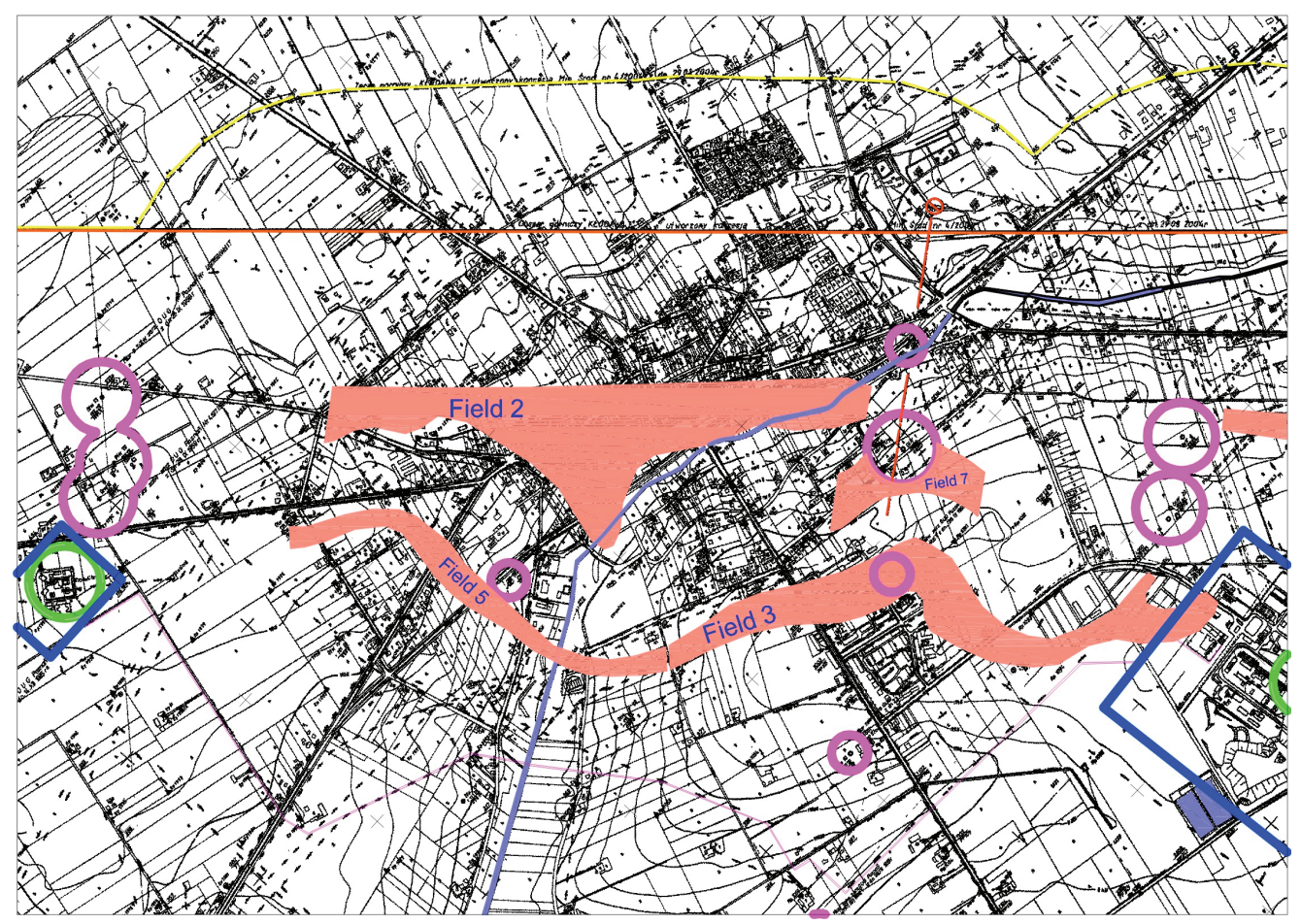

Fig. 1. Location of field 2, field 3 and field 5 [4]

\section{DESCRIPTION OF THE MATERIAL UNDER INVESTIGATION}

As a result of macroscopic assessment of the material taken a great variety of white rock salt structures was found, ranging from completely chaotic to clearly oriented, with single concentrations of big crystals amongst fine- and medium-crystalline mass and chaotic structure of pink rock salt.

From the delivered samples NNS in the shape of cubes with the side of approximately $15 \mathrm{~cm}$ and shapeless solids, there were made, by means of dry treatment method, 49 laboratory samples of white salt (field 2) and 36 samples of pink salt (19 samples from field 3 and 17 samples from field 5), in the shape of cylinder according to ISRM recommendation (diameter $50 \mathrm{~mm}$, height $100 \mathrm{~mm}$ ), with the control of parallelism of the bases [6].

The samples made were weighed and, on this basis, unit weight was determined, which value for particular kinds of salts is included in the following ranges:

- white rock salt (field 2): $\quad 20.4-21.36 \mathrm{kN} / \mathrm{m}^{3}$ (average value $21.11 \mathrm{kN} / \mathrm{m}^{3}$ ),

- pink rock salt (field 3): $\quad 19.95-21.34 \mathrm{kN} / \mathrm{m}^{3}$ (average value $21.05 \mathrm{kN} / \mathrm{m}^{3}$ ),

- pink rock salt (field 5): $\quad 20.80-21.28 \mathrm{kN} / \mathrm{m}^{3}$ (average value $21.03 \mathrm{kN} / \mathrm{m}^{3}$ ). 


\section{PROPERTIES OF ROCK SALT IN UNIAXIAL COMPRESSIVE AND TENSILE TESTS}

Salt strength testing in uniaxial compression was done on a hydraulic press at constant speed of applying load. While testing, the values of axial, radial and volumetric displacement were recorded with accuracy to $0.01 \mathrm{~mm}$. Because the macroscopic assessment demonstrated, for many samples, clear, oriented lay-out of salt grains, radial displacements were measured in two mutually perpendicular directions in half-height of the sample. On the basis of the run of stress-strain characteristics (Fig. 2) for each sample, the value of breaking stress was calculated as well as linearity limit of perpendicular strains and macro-dilatancy limit, and also in percentages the relation of these values with reference to $R_{c}$.

For the complete assessment of strength properties of the salt tested, tensile tests were also done. Tensile strength was determined by compression of side surface of cylinder samples along opposite generating lines (so-called Brazilian method).

Calculated values of strength and strain parameters are illustrated in Table 1 and Table 2.

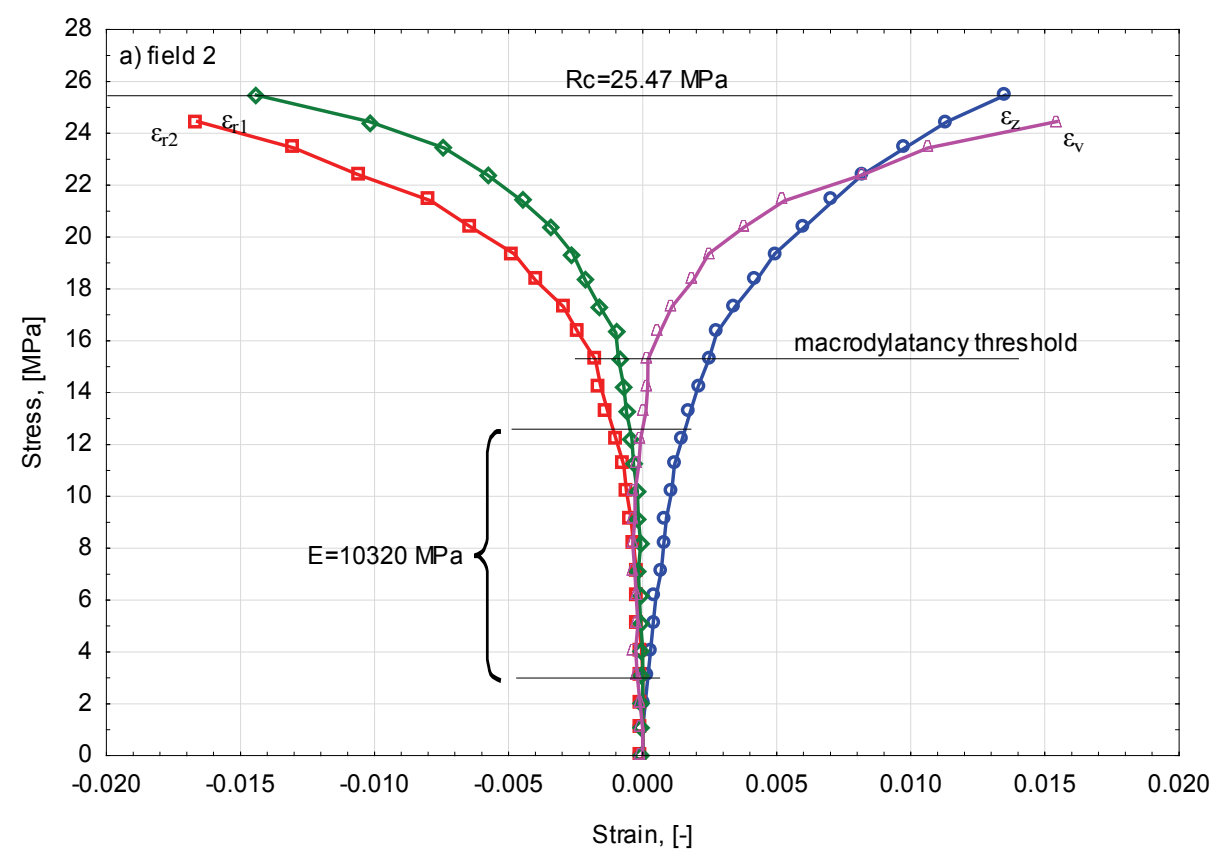

a) 


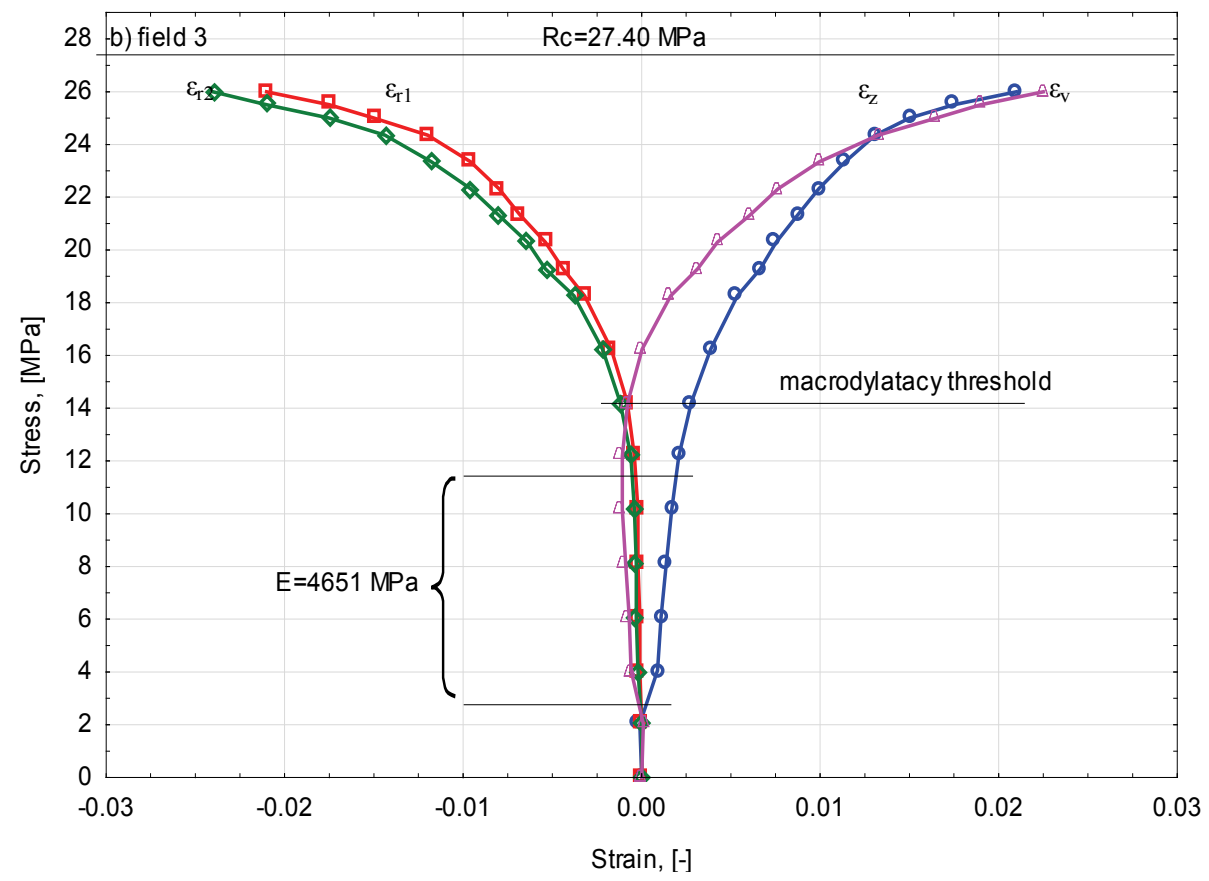

b)

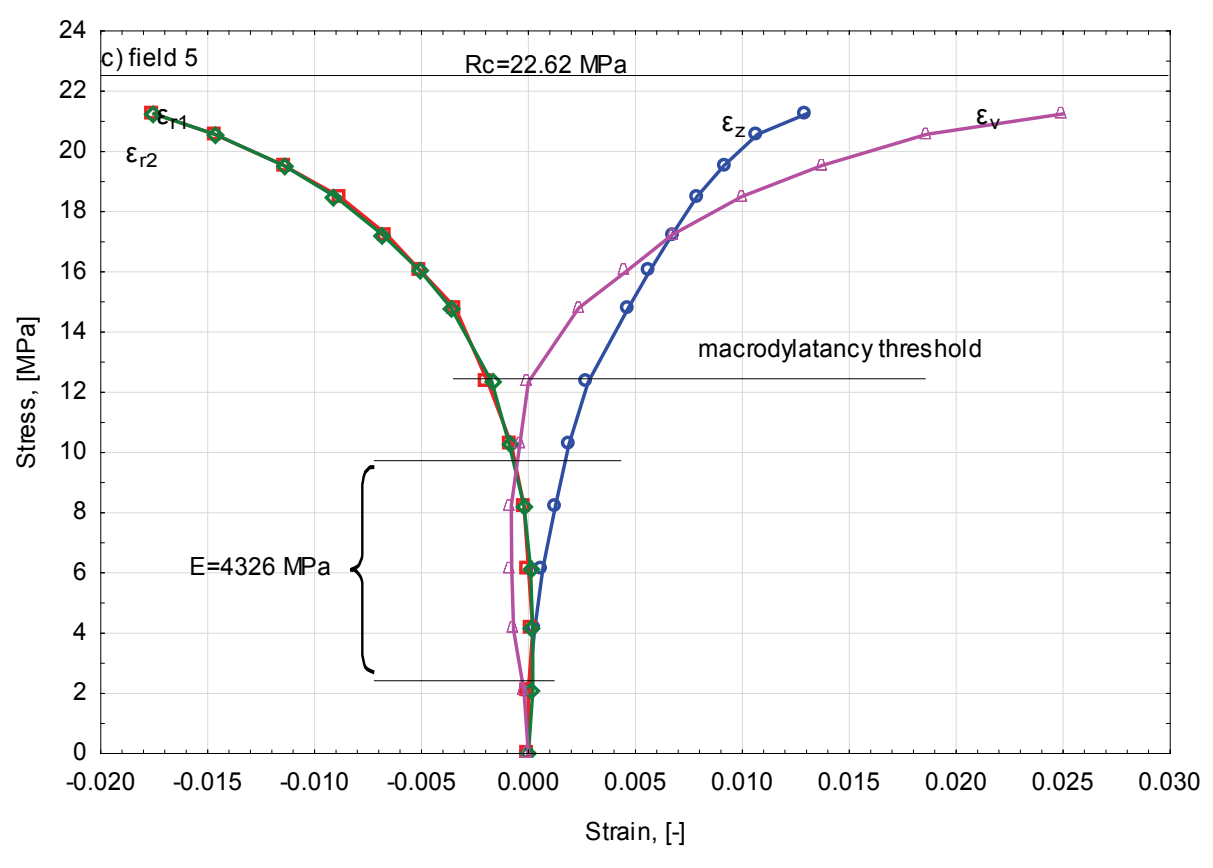

Fig. 2. Illustrative stress-strain characteristics of rock salt in Kłodawa diapir:

(a) field 2 (sample 2/2), (b) field 3 (sample 3/14), (c) field 5 (sample 5/11) 
Table 1

Stress properties of rock salt during uniaxial compressive and tensile tests

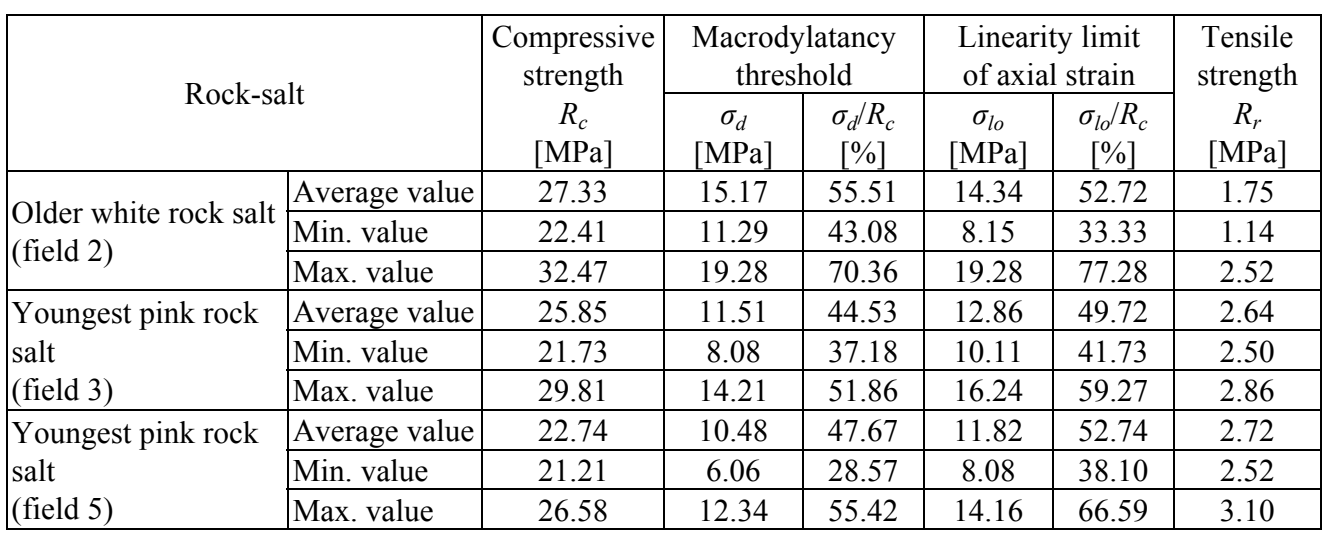

Strain parameters of rock salt during uniaxial compression tests

\begin{tabular}{|l|l|c|c|c|c|c|}
\hline \multirow{2}{*}{\multicolumn{2}{|c|}{ Rock-salt }} & \multicolumn{2}{c|}{$\begin{array}{c}\text { Coefficient of longitudinal } \\
\text { strain } E,[\mathrm{MPa}]\end{array}$} & \multicolumn{3}{c|}{$\begin{array}{c}\text { Coefficient of transverse } \\
\text { strain } v,[-]\end{array}$} \\
\cline { 3 - 7 } & & $\begin{array}{c}\text { in linearity } \\
\text { range }\end{array}$ & $\begin{array}{c}\text { in range, } \\
0.2-0 / 8 R_{c}\end{array}$ & $\begin{array}{c}\text { in linearity } \\
\text { range, } v_{1}\end{array}$ & $\begin{array}{c}\text { in linearity } \\
\text { range, } v_{2}\end{array}$ & $\begin{array}{c}\text { Average } \\
\text { value }\end{array}$ \\
\hline \multirow{2}{*}{$\begin{array}{l}\text { Older } \\
\text { white rock salt } \\
\text { (field 2) }\end{array}$} & Average value & 6886 & 2221 & 0.9 & 0.32 & 0.30 \\
\cline { 2 - 7 } & Min. value & 4113 & 1414 & 0.11 & 0.10 & 0.17 \\
\cline { 2 - 7 } $\begin{array}{l}\text { Youngest } \\
\text { pink rock salt } \\
\text { (field 3) }\end{array}$ & Max. value & 10320 & 3978 & 0.48 & 0.46 & 0.42 \\
\hline \multirow{2}{*}{$\begin{array}{l}\text { Youngest } \\
\text { pink rock salt } \\
\text { (field 5) }\end{array}$} & Average value & 3772 & 1749 & 0.23 & 0.32 & 0.29 \\
\cline { 2 - 7 } & Min. value & 2157 & 1237 & 0.18 & 0.13 & 0.13 \\
\cline { 2 - 7 } & Max. value & 6867 & 2143 & 0.30 & 0.49 & 0.49 \\
\cline { 2 - 7 } & Min. value & 2292 & 1973 & 0.36 & 0.36 & 0.36 \\
\hline
\end{tabular}

For each sample longitudinal strain coefficient was determined, calculated both in the range of axial strain linearity and also according to ISRM recommendations (in the range $0.2-0.8 R_{c}$ ), and transverse strain coefficient calculated in the range of transverse strain linearity (Table 2). Transverse strain coefficients calculated in the range of $0.2-0.8 R_{c}$ are higher than 0.5 and lose their physical sense.

Analysis of numerical values of the parameters obtained in uniaxial compression tests indicates relatively slight diversification of strength properties of the samples tested (field 2: $R_{\text {cav }}=27.33 \mathrm{MPa}$, field 3: $R_{\text {cav }}=25.87 \mathrm{MPa}$, field 5: $R_{\text {cav }}=22.74 \mathrm{MPa}$ ). The threshold of macro-dilation (abnormal increase in rock volume, which is characterized by the value of coefficient of transverse expansion higher than 0.5 ) for white rock salt is 
in the range of $11.29-19.28 \mathrm{MPa}$, which amounts to $55 \%$ of strength limit $R_{c}$, whereas for rock-salt in field 3 and field 5 is contained accordingly in the range of 8.0814.21 MPa and 6.06-12.34 MPa, which on average amounts to $44 \%$ (field 3 ) and $46 \%$ (field 5) of strength limit $R_{c}$. Similarly, apparent linearity limit of axial strain for white rock-salt is included in range $8.15-19.28 \mathrm{MPa}$, which amounts to $53 \% R_{c}$, on average, and for pink rock salt in range of 10.11-16.24 MPa (field 3) and 8.08-14.16 MPa (field 5), which accordingly amounts to 50\% (field 3) and 53\% (field 5).

Strain parameters, though, show significantly greater diversity. Module $E$ in the range of axial strain linearity changes for white rock salt in range of 4.1-10.3 GPa (average value: 6.9 Gpa), and for pink rock-salt 2.2-6.9 GPa (field 3) and 2.3-6.8 GPa (field 5) with average values $3.8 \mathrm{GPa}$, identical for both fields.

\section{TRIAXIAL COMPRESSIVE TESTS}

Triaxial compressive tests were done in hydraulic press equipped with pressure chamber, which provided keeping up the applied side pressure, constant during the tests, in the course of steering the constant pressure of axial stress.

Taking into consideration the deposition conditions of Kłodawa diapir and the influence of depth on the values of geostatic pressures, triaxial compressive tests were done at radial pressures ranging from 2-25 $\mathrm{MPa}$.

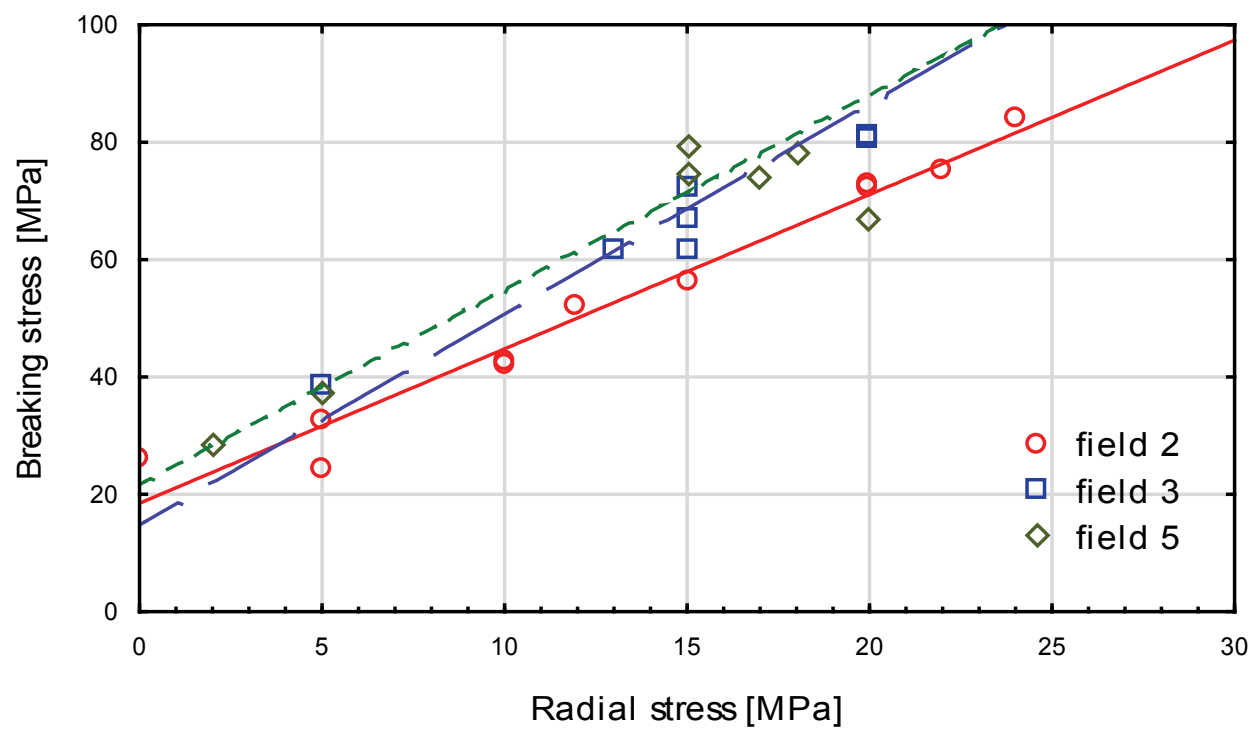

Fig. 3. Dependence of breaking stress in triaxial compressive tests on radial stress values 
The results of triaxial compressive tests are presented in the form of dependence of breaking stress on radial stress values (Fig. 3), and dependence of maximum shear stresses on average values of normal stresses at failure (Fig. 4).

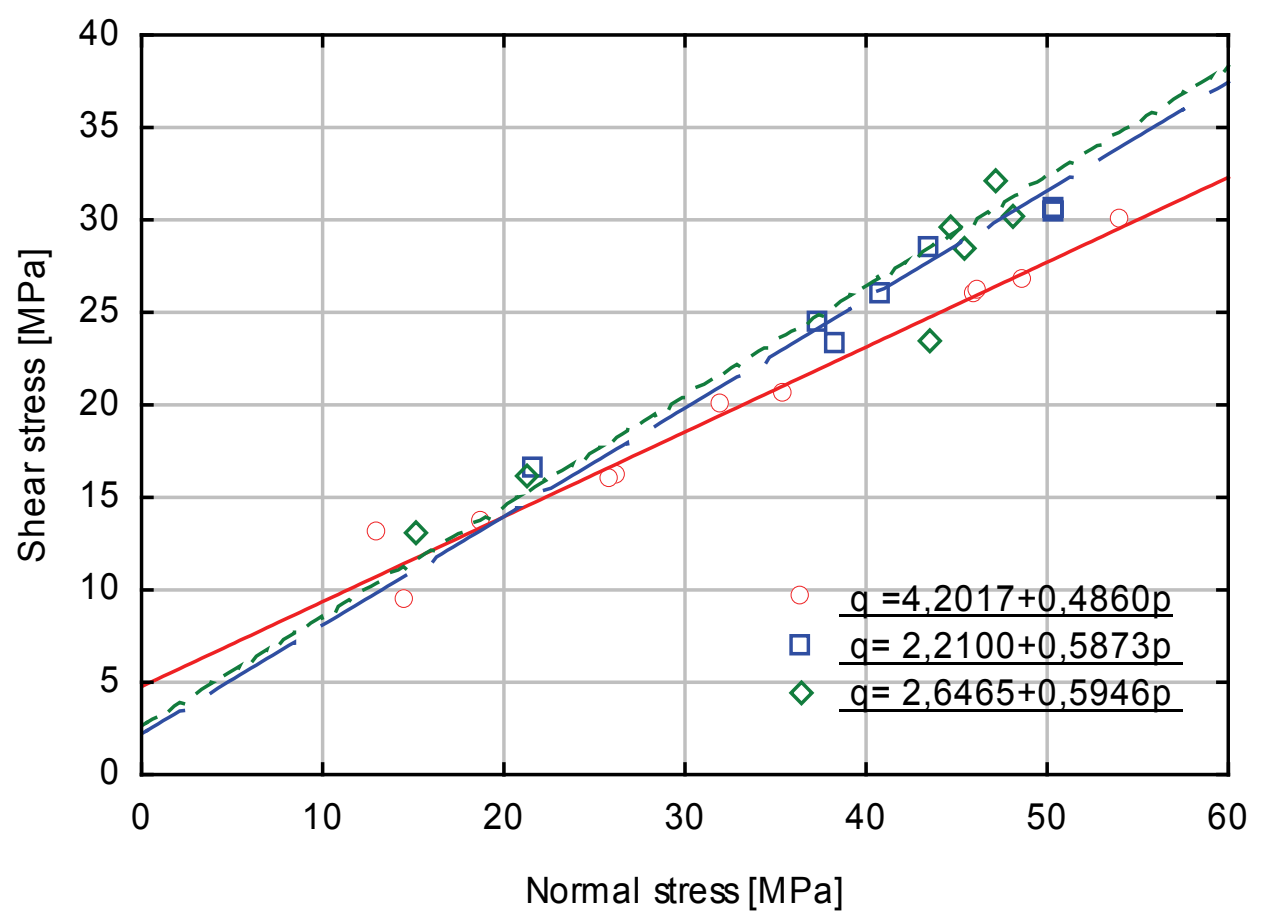

Fig. 4. Dependence of maximum shear stresses on average values of normal stresses at failure

In the whole range of applied pressures, linear dependence of breaking stresses on the values of radial stresses (Fig. 3) is characteristic of white rock salt and pink rock salt in field 3, whereas, for pink rock salt in field 5, linear dependence occurs only in the range of pressures which do not exceed values of approximately $15 \mathrm{MPa}$. However, a small number of the tests done do not allow, though, formulating appropriate numerical conclusions.

In the whole range of applied radial stresses, though, relation of maximum shear stresses at failure with average normal stress (Fig. 4) for all kinds of rock salt can be circumscribed with the Coulomb-Mohr condition, as the dependence:

$$
\frac{1}{2}\left(\sigma_{1}-\sigma_{3}\right)-\frac{1}{2}\left(\sigma_{1}+\sigma_{3}\right) \sin \varphi-k \cos \varphi=0
$$

where 
$k$ - cohesion,

$\varphi$ - internal friction angle, and

$$
\begin{aligned}
& \frac{1}{2}\left(\sigma_{1}-\sigma_{3}\right)=q, \\
& \frac{1}{2}\left(\sigma_{1}+\sigma_{3}\right)=p .
\end{aligned}
$$

Correspondingly obtained for rock salt:

- white (field 2): $\quad q=0.4860 p+4.2017$,

- pink (field 3): $\quad q=0.5873 p+2.2100$,

- pink (field 5): $\quad q=0.946 p+2.6465$.

On this basis for the samples tested, in the whole range of radial stresses not exceeding the value of $25 \mathrm{MPa}$, equation of limit equilibrium can be formulated as classical Coulomb condition with rectilinear envelope and the following parameters:

- older white rock salt (field 2): cohesion: 4.20 MPa, internal friction angle: $29.08^{\circ}$,

- youngest pink rock salt (field 3): cohesion: $2.73 \mathrm{MPa}$, internal friction angle: $35.97^{\circ}$,

- youngest pink rock salt (field 5): cohesion: $3.29 \mathrm{MPa}$, internal friction angle: $36.48^{\circ}$.

This equation, with sufficient accuracy, circumscribes rock salt strength condition in the depth interval from which the test samples were taken.

\section{SUMMARY}

The recorded characteristics of axial strains, transverse strains and volume strains for white and pink rock salts demonstrate non-linearity in the whole range of stresses. Strength properties of the samples tested demonstrate relatively small diversification, whereas strain parameters are characterized by significantly greater variability. Above the macro-dilatancy threshold, the increase in stresses is accompanied by a significant increase in transverse strains and increase in volume strains, which results from progressive rock disintegration (for white rock salt, the macro-dilatancy threshold amounts to $55 \%$ of strength limit, whereas for pink rock salt, it oscillates in the range of $45 \%$ ).

Tensile strength for the kinds of rock analyzed salts slightly changes, however, because of a small number of the tests done, it is difficult to get statistical estimation.

The obtained strength parameters, cohesion and internal friction angle for pink rock salt (field 3 and 5) differ insignificantly from each other, whereas these parameters characterizing field 2 (white rock salt) demonstrate significant difference in com- 
parison with pink rock salt, where cohesion is higher by approximately $28 \%$, and internal friction angle is lower by $25 \%$. To specify numerical values of the parameters of Coulomb condition and their extrapolation on the diapir area, where further mining activity is planned, requires making properly numerous series of tests at different radial stresses and statistical estimation of the results obtained.

\section{REFERENCES}

[1] Flisiak D., Kolano M., Research on Geomechanical Properties of Rock Salt in Kłodawa Diapir, AGH Journal of Mining and Geoegineering, Kraków, Vol. 36, No. 2, 2012.

[2] GARLICKi A., SzYBIST A., Salinarne osady polskiego cechsztynu z solami potasowo-magnezowymi, Gospodarka Surowcami Mineralnymi, t. 2, z. 3-4, PAN, Kraków, 1986.

[3] HwaŁeK S., Górnictwo soli kamiennych i potasowych, Wydawnictwo „Sląsk”, 1971.

[4] Mapa sytuacyjno-wysokościowa, Skala 1:5000

[5] Praca zbiorowa, Laboratoryjne badania właściwości geomechanicznych soli kamiennej z wysadu Kłodawa, Katedra Geomechaniki, Budownictwa i Geotechniki AGH, Kraków, 2011 (typescript).

[6] UluSAY R., HudSON J.A. (eds.), The complete ISRM suggested methods for rock characterizations, testing and monitoring: 1974-2006, Amsterdam, Turkey, 2007. 